\title{
PENGEMBANGAN THE IMPLICIT ASSOCIATION TEST PADA SIKAP MAHASISWA TERHADAP PERILAKU BERWIRAUSAHA
}

\author{
Anna Maria Amanda Putri, Vincent Leonardi, Margareta Nina Aprilia \\ Universitas Katolik Indonesia Atma Jaya \\ E-mail:amandatjan7892@gmail.com,vincent.leonardi16@yahoo.com, \\ margaretanina94@gmail.com
}

\begin{abstract}
This study is an effort of developing a measurement with the Implicit Association Test (IAT) method. The researchers tried to use this approach in industrial organizational psychology research, particularly to measure the construct of attitudes towards entrepreneurship. College perform an important role on preparing qualified graduates so as to produce reliable entrepreneur. The sampling technique was by using convenience sampling technique of 40 active college students on Atma Jaya Catholic University of Indonesia. Based on the result of discriminant validity, we obtained a negative correlation that is not significant $(r=-0,266 ; p=0,97)$ with an external instrument measuring depression. Alat Ukur Sikap terhadap Perilaku Berwirausaha were also reliable with coefficient 0.73 using split-half method. We concluded that Alat Ukur Sikap terhadap Perilaku Berwirausaha is a valid instrument based on discriminant validity. We also give recommendations for further studies on the end of the paper.
\end{abstract}

Keywords: Implicit Association Test; Entrepreneurship; Attitudes

\begin{abstract}
Abstrak
Studi ini bertujuan untuk mengembangkan alat ukur sikap, secara spesifik pengukuran sikap implisit terhadap perilaku berwirausaha menggunakan metode Implicit Association Test (IAT) secara valid dan reliabel. Dunia perkuliahan memegang peran penting dalam menyiapkan lulusan berkualitas yang dapat berkompetisi dalam dunia wirausaha. Penelitian ini melibatkan 40 orang partisipan. Partisipan dalam penelitian adalah mahasiswa aktif yang berkuliah di Universitas Katolik Indonesia Atma Jaya Jakarta dengan metode convenience sampling. Berdasarkan hasil pengujian validitas diskriminan, diperoleh hasil bahwa terdapat korelasi negatif yang tidak signifikan $(r=-0,266 ; p=0,97)$ dengan alat ukur depresi. IAT juga memperoleh hasil koefisien reliabilitas sebesar 0,73 dengan menggunakan metode split-half. Hasil penelitian menunjukan bahwa Alat Ukur Sikap terhadap Perilaku Berwirausaha merupakan alat ukur yang valid berdasarkan pengujian validitas diskriminan. Setelah itu, kami memberikan rekomendasi untuk penelitian serupa di masa mendatang.
\end{abstract}

Kata kunci: Implicit Association Test; Perilaku Berwirausaha; Sikap

\section{PENDAHULUAN}

Indonesia memiliki jumlah penduduk terbanyak keempat di dunia, setelah China, India, dan Amerika Serikat (Central Intelligence Agency, 2017). Berdasarkan sensus penduduk pada tahun 2010 yang dilakukan oleh BPS, tercatat bahwa jumlah penduduk Indonesia adalah 237 juta orang dan akan terus bertambah di tahun 2020 (Badan Pusat 
Statistik, 2013). Jumlah penduduk Indonesia yang terus bertambah dari tahun ke tahun diiringi dengan pertambahan jumlah penduduk yang bekerja (Badan Pusat Statistik, 2013). Di lain pihak, Sumarna selaku Komite Tetap Sertifikasi Tenaga Kerja Kamar Dagang dan Industri (Kadin) menyebutkan bahwa peningkatan jumlah penduduk Indonesia tidak diiringi dengan jumlah lapangan kerja yang tersedia. Secara lebih spesifik, penduduk Indonesia yang dimaksud adalah angkatan kerja. Jadi ada diskrepansi antara angkatan kerja dan lapangan kerja berakibat pada angka pengangguran (Baiquni, 2014)

Pengangguran merupakan keadaan yang terjadi ketika seseorang yang merupakan golongan dari angkatan kerja tidak terserap oleh pasar kerja (Sukirno, 2000). Berdasarkan sensus ekonomi yang dilakukan BPS pada tahun 2017, diketahui bahwa tingkat pengangguran di Indonesia berangsur menurun pada persentase $0,48 \%$ pada tahun 2015 sampai 2017. Hal ini menunjukkan bahwa upaya yang dilakukan pemerintah terkait penciptaan lapangan pekerjaan cukup berhasil menekan tingkat pengangguran. Adanya penurunan tingkat pengangguran di Indonesia masih tidak dapat disandingkan dengan negara lainnya. Indonesia berada pada urutan tertinggi berdasarkan tingkat pengangguran dibandingkan 11 negara Asia lainnya (Trading Economics, 2017), seperti Kamboja (0,3\%, [2017]), Thailand (1,1\%, [2017]), Vietnam (2,09\%, [2017]), Singapura (2,2\%, [2017]), Jepang $(3,0 \%$, [2016]), Hong Kong (3,1\%, [2017]), India (3,4\%, [2017]), Malaysia (3,5\%, [2017]), Taiwan (3,9\%, [2016]), China (3,95\%, [2017]) dan Korea Selatan (4,9\%, [2016]). Oleh karena itu, masalah pengangguran di Indonesia masih menjadi perhatian pemerintah.

Salah satu upaya pemerintah untuk menekan jumlah pengangguran adalah dengan meningkatkan jumlah wirausahawan (Kemendagri, 2013). Peningkatan jumlah wirausahawan akan menyerap angkatan kerja di Indonesia, sehingga dapat menekan jumlah pengangguran (Iskandar, dalam Putra, 2013). Hal serupa diungkapkan oleh Jonni Mardizal selaku Pelaksana Tugas Deputi Bidang Pengembangan Pemuda Kemenpora bahwa program peningkatan wirausahawan merupakan upaya menurunkan tingkat pengangguran di Indonesia. Pemuda Indonesia diharapkan mampu membangun wirausaha (Koes, 2017) agar dapat meningkatkan kemajuan ekonomi Indonesia (Manik \& Sidharta, 2016). Menurut Hadian, Machmud, Junaha dan Sidharta (2015), peningkatan wirausaha dimulai dari dunia akademik yaitu bangku perkuliahan. Dunia perkuliahan memegang peran penting dalam menyiapkan lulusan berkualitas yang dapat berkompetisi dalam dunia wirausaha (Hadian, Machmud, Junaha \& Sidharta, 2015). Berdasarkan penjelasan tersebut, untuk menekan angka pengangguran di Indonesia, pemerintah harus memaksimalkan aktivitas wirausaha. Secara khusus aktivitas wirausaha yang harus ditingkatkan ada pada jenjang perkuliahan, sehingga mampu menciptakan lapangan pekerjaan bagi masyarakat. Atas dasar tersebut, peneliti memilih mahasiswa sebagai populasi penelitian. 
Secara umum, seorang individu akan dihadapkan pada dua buah pilihan karir ketika menyelesaikan tingkat pendidikannya (Kolvereid, 1996). Pilihan pertama adalah sebagai employee atau individu yang pekerjaannya bergantung pada lapangan pekerjaan yang ada. Pilihan kedua adalah sebagai self-employee atau individu yang bekerja secara mandiri dan mampu menciptakan lapangan pekerjaan minimal untuk dirinya sendiri, dalam hal ini disebut wirausaha. Sebagian besar masyarakat Indonesia cenderung memilih menjadi employee (Survei Litbang Media Group; Survei Tenaga Kerja Nasional, dalam Suharyadi, 2007). Hal ini dibuktikan dengan jutaan penduduk Indonesia yang tiap tahunnya berbondong-bondong mendaftar untuk menjadi Calon Pegawai Negeri Sipil (Rachman, 2017).

Menteri Koperasi dan UKM Puspayoga (depkop.go.id, 2017) menargetkan pada awal tahun 2017, wirausaha di Indonesia mencapai 4\%, namun pada kenyataannya hanya 3,1\% masyarakat yang menjalani wirausaha. Secara lebih spesifik pada mahasiswa, Kemenkop UKM (dalam Mopangga, 2014) menyebutkan bahwa hanya 7,4\% dari 4,8 juta mahasiswa yang menggeluti dunia wirausaha. Hal tersebut menunjukan minat mahasiswa untuk berwirausaha masih sangat rendah (Mopangga, 2014). Zimmerer mengatakan bahwa hal ini dapat dikarenakan menjadi wirausaha memiliki tingkat risiko yang tinggi. Risiko tersebut berupa pendapatan yang tidak menentu, kerugian akibat kehilangan modal investasi, memerlukan waktu yang relatif lama dan kualitas kehidupan yang cenderung rendah walaupun usaha dapat dikatakan telah berhasil (Suryana, 2014).

Self-employee atau wirausaha menurut Meredith (Suryana, 2014), merupakan suatu pekerjaan atau karier yang bersifat fleksibel serta imajinatif, mampu merencanakan, mengambil risiko, keputusan, dan tindakan untuk mencapai tujuan. Dalam memahami perilaku wirausaha, terdapat dua pandangan yang seringkali digunakan (Liñán, 2014). Pandangan pertama dikemukakan oleh Shapero dan Sokol (Liñán, 2014) mengenai teori entrepreneurial events. Pandangan kedua dikemukakan oleh Ajzen (Liñán, 2014) mengenai theory of planned behavior. Entrepreneurial events membahas mengenai interaksi faktor eksternal yang memengaruhi persepsi yang dimiliki seorang individu.

Pandangan yang kedua dikemukakan oleh Ajzen secara lebih komprehensif mengenai theory of planned behavior. Ajzen memandang bahwa seluruh perilaku manusia memiliki alasan, terkontrol dan terencana sesuai dengan pertimbangan individu tersebut mengenai perilaku yang akan dijalankan (Fayolle dan Gailly, 2005). Faktor penting dalam melakukan suatu perilaku terletak pada intensi yang dimiliki oleh individu. Dalam membentuk intensi, terdapat tiga faktor determinan pembentuk intensi, antara lain sikap terhadap perilaku, subjective norms dan perceived behavioral control. Ketiga faktor determinan tersebut saling berinteraksi dalam pembentukan intensi (Ajzen, 1985).

Faktor pertama yaitu sikap, menurut Sarwono (2009) sikap merupakan proses penilaian yang dilakukan oleh seseorang terhadap suatu objek. Sikap terhadap suatu objek dapat tergolong positif (favorable) atau negatif (unfavorable). Dalam proses pembentukan 
sikap, individu akan melakukan respon evaluatif terhadap objek sikap yang muncul di lingkungannya. Respon evaluatif akan disimpan dalam memori, berbentuk informasi atau believe. Believe yang tersimpan dalam memori membentuk sikap terhadap objek yang muncul di lingkungan individu tersebut (Ajzen, dalam Fayolle \& Gailly, 2005).

Faktor kedua adalah subjective norms, merupakan norma yang diterima individu ketika harus atau tidak melakukan perilaku tertentu. Subjective norms dipengaruhi oleh normative belief dan internal locus of control yang dimiliki oleh individu. Faktor terakhir adalah perceived behavioral control, merupakan penilaian individu mengenai tingkat kesulitan terhadap perilaku tertentu. Faktor ini berhubungan dengan persepsi yang individu terhadap perilaku. Bagan 1 merupakan visualisasi atas penjabaran teori Planned Behavior (Ajzen, 1991).

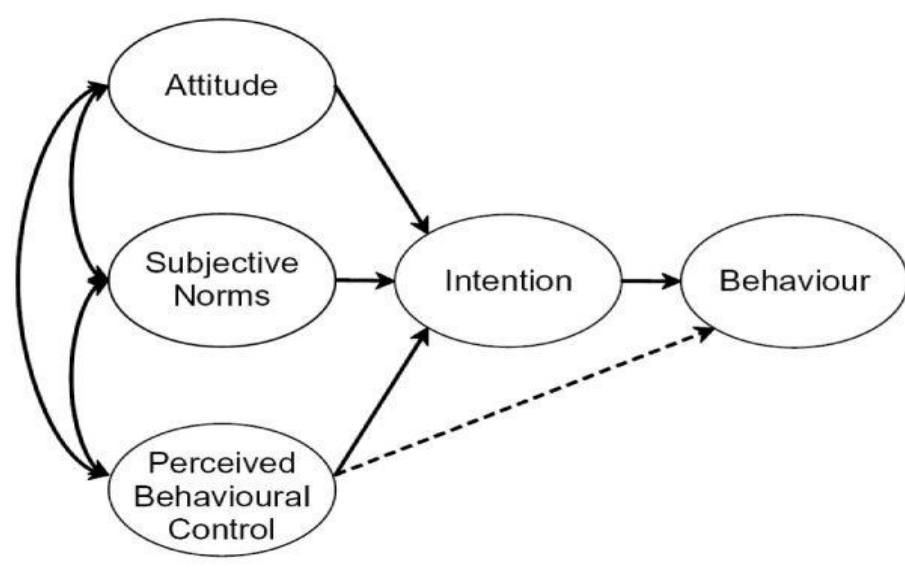

Gambar 1

Theory of planned behavior (Ajzen, 1991)

Krueger, Reilly dan Carsrud (dalam Liñán, Rodríguez-Cohard, \& Rueda-Cantuche, 2005) menyebutkan bahwa konsep entrepreneurial event dan theory of planned behavior memiliki kesamaan yang saling melengkapi. Liñán, Rodríguez-Cohard dan RuedaCantuche (2005) mengemukakan bahwa theory of planned behavior merupakan teori yang lebih terstruktur dibandingkan dengan entrepreneurial event. Selain itu, konsep entrepreneurial event hanya melingkupi nilai yang dimiliki individu dan tidak memprediksi atau membentuk perilaku secara langsung, sedangkan theory of planned behavior secara teoritis mampu memprediksi perilaku. Berdasarkan penjabaran tersebut, peneliti memilih theory of planned behavior yang dikemukakan oleh Ajzen untuk dapat mengukur sikap wirausaha yang dimiliki oleh individu.

Pendekatan sikap telah menjadi pendekatan analisis yang dulu digunakan untuk memprediksi munculnya suatu perilaku (Robinson; Krueger, Reilly \& Carsrud, dalam Liñán, Rodríguez-Cohard, \& Rueda-Cantuche, 2005). Selain itu variabel sikap yang 
menunjukan pengaruh signifikan dibandingkan dengan variabel subjective norms dan variabel perceived social norms dalam theory of planned behavior (Gopi \& Ramayah, 2007; Alam \& Sayuti, 2011; Han, Hsu, \& Sheu, 2010; George, 2004). Secara lebih spesifik penelitian mengenai wirausaha menunjukkan bahwa variabel sikap memiliki pengaruh paling kuat dibandingkan variabel lainnya (Gird \& Bagraim, 2008; Carr \& Sequeira, 2006). Berdasarkan hal tersebut, sikap dipilih sebagai variabel yang digunakan dalam alat ukur karena memiliki pengaruh yang lebih kuat terhadap intensi dibandingkan subjective norm dan perceived behavioral control dalam theory of planned behavior.

Sikap merupakan evaluasi yang dimiliki individu terhadap keseluruhan aspek dalam kehidupan, seperti keberadaan individu lain, objek fisik, perilaku atau peraturan tertentu. Sikap yang dimiliki individu dapat memengaruhi individu dalam memunculkan suatu perilaku tertentu (Ajzen \& Fishbein, 1977). Menurut Lindsey dan Schooler (2000) sikap terdiri atas dua jenis, yaitu eksplisit dan implisit. Dalam kaitannya dengan perilaku, sikap implisit ditemukan efektif memprediksi kemunculan suatu perilaku tertentu (Greenwald, Poehlman, Uhlman \& Banaji, 2009; McConnel \& Leibold, 2001; Maison, Greenwald \& Bluin, 2004). Hasil temuan tersebut menarik peneliti untuk menggunakan sikap implisit dalam konsep pengukuran alat ukur kewirausahaan.

Sikap implisit merupakan ketiadaan conscious awareness terhadap sikap yang dimiliki individu (Payne \& Gawronski, 2010). Lain halnya dengan sikap eksplisit yang dapat dilaporkan secara langsung tentang apa yang dirasakan individu, misalnya dengan menggunakan self-report measurement, sikap implisit diukur secara tidak langsung menggunakan pengukuran implisit (Hafiyah, Puri \& Shadewi, 2011). Pada pengukuran menggunakan self-report measurement, partisipan belum tentu menyadari perasaan yang sesungguhnya (Nisbett \& Wilson dalam Wardani \& Analya, 2012). Kekurangan lainnya dalam penggunaan self-report measurement adalah partisipan tidak selalu memberikan jawaban yang sepenuhnya dapat dipercaya, sekalipun tidak mencantumkan identitas diri (Wittenbrink \& Schwartz, 2007). Hal lainnya yang merupakan kelemahan dari self-report measurement adalah jawaban yang diberikan partisipan dapat berubah, tergantung konteks dan tempat diselenggarakannya pengukuran (Wittenbrink \& Schwartz, 2007). Berdasarkan kekurangan dari metode pengukuran eksplisit, maka berkembang metode pengukuran implisit (Wardani \& Analya, 2012).

Metode pengukuran sikap implisit ini disebut the Implicit Assossication Test (Wittenbrink \& Schwartz, 2007). Implicit Association Test atau IAT merupakan pengukuran implisit yang sangat menonjol dan tinggi akurasi responnya (Mocigemba, Klauer, Sherman \& 2010). Pengukuran sikap implisit mampu menghindarkan respons partisipan yang cenderung ingin terlihat baik secara sosial (social desirability effects) atau ingin memenuhi apa yang dicari oleh peneliti (evaluation apprehension) (Mocigemba, Klauer, Sherman \& 2010). IAT digunakan untuk mengukur sikap implisit yang diasosiasikan dengan tidak adanya conscious introspection dan merefleksikan atribut 
psikologis yang secara introspektif tidak dapat diakses (Greenwald, McGhee, \& Schwartz, 1998). Secara umum, IAT mengestimasi konstruk yang ingin diketahui tanpa meminta partisipan secara langsung memberikan laporan dan partisipan tidak menyadari bahwa sikap yang ia miliki terhadap konstruk tersebut sedang dinilai.

Sejak pertama dipublikasikan, penelitian mengenai IAT menjadi salah satu metode pengukuran yang paling sering digunakan (Stuttgen, Vosgerau, Messner \& Boatwright, 2011). Jumlah pencarian pada mesin pencari Google mengenai Implicit Association Test telah mencapai 79.000 pada Maret 2011, sebagai perbandingan Big Five Personality Test hanya mencapai 38.000 (Stuttgen, Vosgerau, Messner \& Boatwright, 2011). Di Indonesia sendiri, IAT telah beberapa kali dipergunakan oleh para peneliti seperti Hafiyah, Puri dan Shadewi (2011) untuk mengukur sikap antar kelompok Islam-Kristen di Indonesia, Hartono dan Suwartono (2012) mencoba untuk mengukur self-esteem dengan metode self-report dan implicit association test, dan Wardani dan Analya (2012) menggunakan implicit association test untuk melihat sikap mahasiswa terhadap kepedulian dengan lingkungan.

IAT merupakan metode yang dapat digunakan dalam berbagai bidang (Schacter, 1987). Secara khusus, IAT lebih banyak digunakan dalam bidang-bidang psikologi sosial. Hal ini dikarenakan pengukuran menggunakan IAT merupakan pengukuran sikap yang merupakan konsep yang sangat esensial dan unik yang dimiliki oleh psikologi sosial (Allport, dalam Greenwald, Poehlman, Uhlmann \& Banaji, 2009). Bukan mustahil apabila IAT digunakan oleh bidang psikologi lainnya (Schacter, 1987). Misalnya penggunaan IAT pada bidang industri organisasi mengenai perilaku konsumen (Maison, Greenwald, \& Bruin, 2004) untuk mengetahui sikap konsumen atas suatu brand tertentu. Atas dasar tersebut, peneliti berusaha mengembangkan IAT dalam bidang psikologi industri dan organisasi, secara lebih spesifik pada konstruk perilaku wirausaha.

\section{METODE}

\section{Tujuan}

Pembuatan alat ukur ini bertujuan untuk mengembangkan pengukuran sikap, secara spesifik pengukuran sikap implisit terhadap perilaku berwirausaha yang menggunakan metode implicit association test.

\section{Partisipan}

Partisipan penelitian untuk the implicit association test ini adalah 40 partisipan dengan karakteristik mahasiswa aktif yang berada di Universitas Katolik Atma Jaya 
Jakarta. Metode untuk menentukan partisipan adalah metode non-probability sampling technique berupa convenience sampling.

\section{Prosedur}

Peneliti melakukan studi kepustakaan untuk mencari teori terkait variabel melalui buku, jurnal penelitian dan sumber ilmiah lainnya. Selanjutnya, peneliti juga membentuk alat ukur dengan menggunakan IAT sebagai metode dalam memperoleh data. Dalam membuat IAT, peneliti sebelumnya mengunduh aplikasi Inquisit 5 free trial dari website pengembang metode IAT yaitu https://www.millisecond.com/download/. Dalam website tersebut, terdapat berbagai script dari berbagai penelitian yang diberi nama sebagai Millisecond Test Library yang dapat diunduh secara gratis. Dalam hal ini, peneliti menggunakan script single target IAT yang memungkinkan peneliti untuk menentukan satu target variabel yang ingin di ukur. Peneliti menggunakan penilaian ahli untuk melakukan evaluasi kesesuaian serta ketepatan alat ukur dengan konstruk teori untuk Alat Ukur Sikap terhadap Perilaku Berwirausaha. Ahli dalam penelitian ini adalah Prof. Dr. Benedicta Prihatin Dwi Riyanti, Psikolog sebagai ahli dalam bidang wirausaha untuk menentukan stimulus yang digunakan. Penggunaan stimulus akhir memperoleh keputusan menggunakan beberapa jenis atribut yang terdiri dari:

Dalam menyusun alat ukur dibutuhkan evaluasi terhadap instrumen alat ukur yang digunakan (Lai, 2013). Lai (2013) menambahkan bahwa evaluasi tersebut berguna untuk memastikan instrumen yang digunakan benar mengukur konstruk yang diinginkan. Salah satu bentuk validitas adalah validitas konstruk menggunakan validitas diskriminan (Anastasi \& Urbina, 2007). Validitas diskriminan merupakan pengujian konstruk untuk memastikan bahwa konstruk yang sedang diukur merupakan konstruk yang unik yang tidak diukur oleh alat ukur lain (Hair, Black, Babin, \& Anderson, 2014). Pada penyusunan alat ukur ini, peneliti menggunakan konstruk depresi sebagai discriminant validity. Bradley dan Roberts (2004) mengemukakan bahwa individu yang memiliki perilaku wirausaha tidak mengalami depresi. Hal tersebut merupakan alasan pemilihan konstruk depresi menjadi diskriminan terhadap konstruk wirausaha.

Keseluruhan hasil akhir memperoleh keputusan mengenai target dan atribut dari the implicit association test; kami melakukan desain alat test ini menjadi 5 blok yang harus dikerjakan secara individual oleh partisipan. Secara umum, partisipan harus melakukan kategorisasi dari stimulus yang muncul. Stimulus akan muncul pada monitor pada setiap blok; partisipan diminta untuk menekan tombol ' $E$ ' ketika stimulus tersebut berada pada kategori sebelah kiri dan menekan tombol ' $\mathrm{I}$ ' ketika stimulus berada pada kategori sebelah kanan. 
Tabel 1

Stimulus Implicit Association Test Atribut Baik dan Atribut Buruk

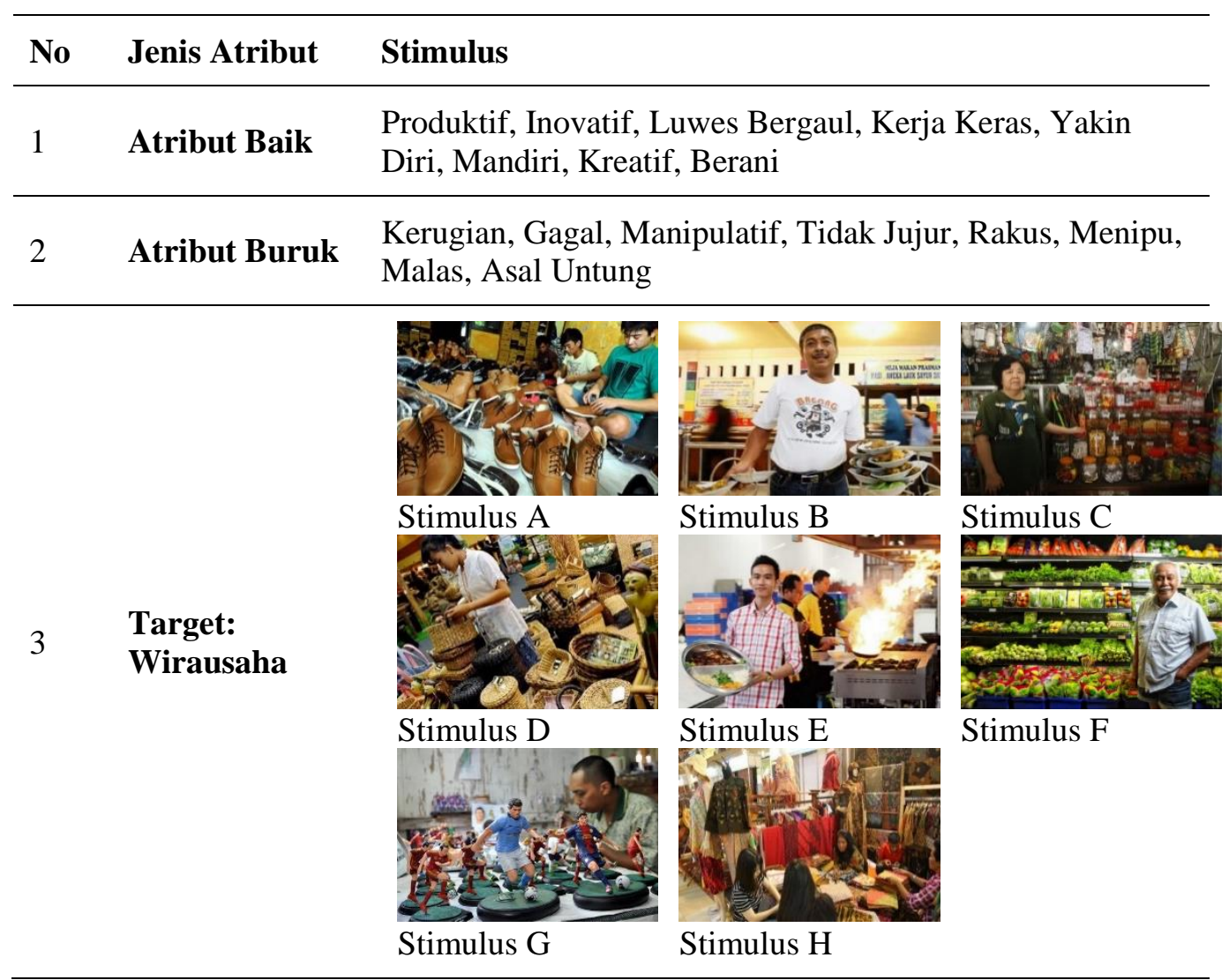

\section{Baik}

Buruk

atau

Wirausaha

Letakkan jari telunjuk kiri Anda pada tombol 'E' untuk kata yang ada pada kategori Baik atau Wirausaha.

Letakkan jari telunjuk kanan Anda pada tombol 'I' untuk kata yang ada pada kategori Buruk.

Jika Anda membuat kesalahan, maka tanda X merah akan muncul untuk melanjutkan, silakan menekan tombol lain.

Kerjakan dengan cepat dan teliti!

Tekan tombol 'Spasi' untuk memulai

Gambar 1

Contoh Intruksi dari Blok 2 


\section{Pengambilan Data}

Dalam tahap pelaksanaan, peneliti mengumpulkan data dengan menggunakan dua buah laptop. Pengumpulan data menggunakan media Google Form dan IAT. Google Form digunakan untuk mengisi pernyataan kesediaan data demografis. Google Form hanya dapat diisi oleh partisipan yang diminta peneliti, sehingga data yang diperoleh sesuai dengan kebutuhan peneliti. Kemudian partisipan diminta untuk mengerjakan alat ukur eksternal Depression Brief IAT dan Alat Ukur Sikap terhadap Perilaku Berwirausaha yang sudah disiapkan dalam laptop.

Pengisian Google Form diperuntukan untuk mengisi informed consent dan data demografis berupa usia, jenis kelamin, intensi wirausaha dan pekerjaan orangtua. Setelah meminta persetujuan partisipan, peneliti memberikan instruksi dalam mengerjakan Depression Brief IAT dan Alat Ukur Sikap terhadap Perilaku Berwirausaha. Selama pengerjaan, partisipan didampingi oleh peneliti, sehingga ketika ada yang kurang jelas atau tidak dimengerti dapat langsung dibantu oleh peneliti. Selain itu, dengan pendampingan secara intensif, peneliti dapat melakukan observasi selama partisipan mengerjakan rangkaian tes tersebut.

Dalam hal ini, peneliti akan terus melakukan observasi dan memberikan arahan tiap blok yang dikerjakan oleh partisipan sampai partisipan mendapatkan hasil nilai D. Setelah nilai D diperoleh, peneliti akan menjelaskan lebih lanjut mengenai variabel yang diukur dalam IAT tersebut dan menjelaskan lebih lanjut mengenai nilai D yang diperoleh oleh partisipan. Jika sudah selesai, maka peneliti akan memberikan ucapan terima kasih atas kontribusi yang dilakukan oleh para partisipan.

\section{Teknik Analisis}

Analisis stimulus pada Implicit Association Test dilakukan dengan cara menghitung persentase respon jawaban benar dan waktu reaksi dari respon yang benar. Menurut Greenwald, Nosek \& Banaji (Wittenbrink \& Schwarz, 2007) syarat stimulus berupa target dan atribut yang dianggap valid dalam alat ukur Implicit Association Test adalah jawaban yang diberikan oleh partisipan tidak kurang dari 300 milisekon dan tidak melebihi dari 10.000 milisekon. Selain itu, partisipan dengan waktu reaksi kurang dari 300 milisekon pada lebih dari $10 \%$ respon, harus dieliminasi. Belum ditemukan sumber yang menyebut batasan minimum jawaban benar yang dapat diterima dalam menganalisis stimulus, namun $80 \%$ masih dapat dipergunakan untuk dijadikan stimulus yang merepresentasikan (Suwartono, Meinarno \& Bawono, 2017).

Peneliti menggunakan pengujian korelasi nilai total alat ukur eksternal dengan nilai D (D-Score). Apabila distribusi data normal ( $p>0,05)$, maka peneliti akan menggunakan 
teknik statistik Pearson-correlations ( $\mathrm{r}$ ), namun apabila data tidak berdistribusi normal ( $\mathrm{p}$ $\leq 0,05$ ), maka peneliti akan menggunakan teknik statistik Spearman rho correlations (rs).

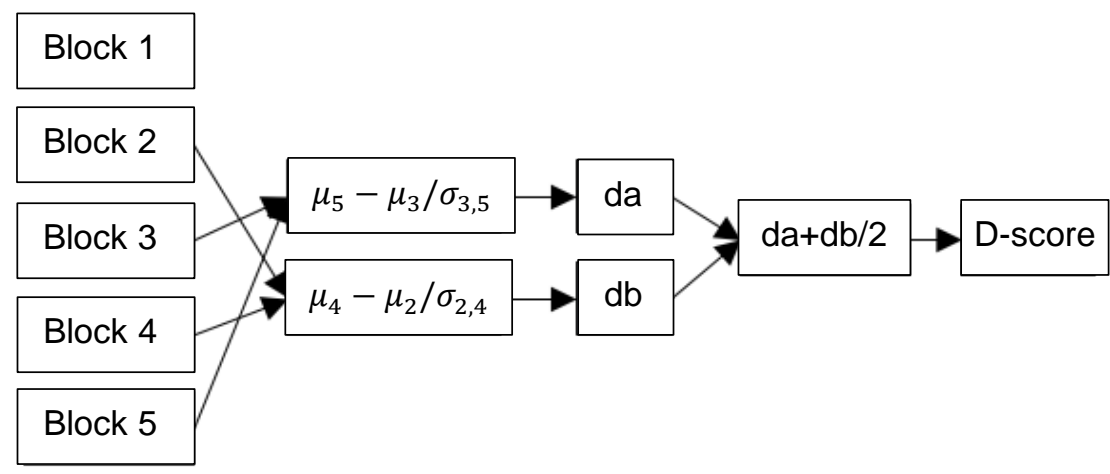

Gambar 2

Penghitungan D-Score Implicit Association Test

Reliabilitas dari instrumen penelitian ini diuji dengan menggunakan metode split-half. Menurut Groth-Marnat (2010) teknik split-half dapat memberikan ukuran konsistensi internal dari soal-soal yang diberikan.

\section{Instrumen Penelitian}

\section{The Implicit Association Test Sikap Terhadap Wirausaha}

The Implicit Assiciation Test atau IAT merupakan alat test baru yang telah mapan serta populer untuk dipergunakan (Greenwald, Mcghee, \& Schwartz, 1998 dalam Perkins et al., 2008). Implicit Association Test menurut Myers (2013) merupakan sebuah test yang berbasis komputer untuk melakukan asesmen mengenai sikap implisit. Test ini menghitung waktu reaksi seseorang yang langsung mengasosiasikan antara objek sikap dan katakata evaluatif. Mudah untuk dipasangkan dan respons yang cepat menjadi sebuah indikasi bahwa terdapat individu memiliki asosiasi ketidak sadaran terhadap suatu objek sikap.

Alat Ukur Sikap terhadap Perilaku Berwirausaha dengan metode the Implicit Association Test teradministrasi menggunakan komputer melalui program Inquisit 5.0, dengan Milisecond selaku pengembang program Inquisit. Pada pengujian ini, partisipan diminta untuk menekan tombol "E" atau tombol "I". Tombol "E" adalah untuk kategori di sebelah kiri, sedangkan tombol "I" adalah untuk kategori di sebelah kanan. Dalam penelitian ini, peneliti menggunakan Single Target IAT yang terdiri atas lima blok.

Blok pertama merupakan blok latihan, dimana partisipan diminta untuk mengkategorisasikan stimulus atribut berupa kata yang tampil di tengah layar ke dalam kategori "Baik" yang berada di sebelah kiri atau kategori "Buruk" yang berada di sebelah kanan. Pada blok kedua dan ketiga, partisipan diminta untuk mengkategorisasikan stimulus atribut berupa kata dan target berupa gambar yang tampil di tengah layar ke 
dalam kategori "Baik" dan "Wirausaha" yang berada di sebelah kiri, atau "Buruk" yang berada di sebelah kanan. Pada blok keempat dan kelima, partisipan diminta untuk mengkategorisasikan stimulus atribut berupa kata dan target berupa gambar yang tampil di tengah layar ke dalam kategori "Baik" yang berada di sebelah kiri, atau "Buruk" dan "Wirausaha" yang berada di sebelah kanan. Dalam hal ini, waktu reaksi tiap partisipan akan dihitung untuk blok 2, blok 3, blok 4, dan blok 5. Tabel 1 merupakan visualisasi dalam bentuk tabel atas susunan alat ukur sikap terhadap perilaku wirausaha dengan metode the Implicit Association Test.

\section{Depression Brief Implicit Association Test}

Alat ukur Depression Brief IAT dapat mengukur sikap individu terhadap dirinya sendiri, apakah individu memiliki asosiasi negatif terhadap dirinya (menunjukan adanya kecenderungan depresi) atau memiliki asosiasi yang positif terhadap dirinya (tidak menunjukan adanya kecenderungan depresi). Pengembangan Depression Brief IAT didasarkan pada cognitive theory of depression yang dikembangkan oleh Beck (Meites, 2008). Depression Brief IAT memiliki enam buah blok yang mengukur kekuatan asosiasi dari empat buah kategori, yaitu dua kategori konsep (Saya dan Bukan Saya) dan dua kategori atribut (Bahagia dan Sedih). Kategori konsep terdiri atas sepuluh stimulus dan kategori atribut terdiri atas sepuluh stimulus. Hasil akhir yang diperoleh dalam Depression Brief IAT dapat menunjukan preferensi atau asosiasi yang dimiliki individu terhadap diri sendiri atau bukan diri sendiri. Ketika individu memiliki asosiasi positif terhadap diri sendiri yang lebih tinggi dibandingkan dengan bukan diri sendiri, maka individu memiliki tingkatan depresi yang rendah. Ketika individu memiliki asosiasi positif terhadap diri sendiri yang lebih rendah dibandingkan dengan bukan diri sendiri, maka individu memiliki tingkat depresi yang tinggi.

Pemilihan depresi sebagai konstruk validitas diskriminan didasarkan pada penelitian Bradley dan Roberts (2004) yang menemukan bahwa depresi dan wirausaha memiliki nilai koefisien korelasi yang rendah $(\mathrm{r}=-0,02, p<0,05)$. Menurut Campbell (dalam Henseler, Ringle \& Sarstedt, 2015), konstruk validitas diskriminan ditentukan pada nilai koefisien korelasi yang tidak berkorelasi tinggi dengan konstruk yang diukur. Nisfiannoor (2009) meyebutkan bahwa nilai koefisien korelasi berentang 0 sampai dengan 0,19 merupakan korelasi yang sangat rendah, atas dasar tersebut peneliti menggunakan konstruk depresi sebagai konstruk yang digunakan dalam validitas diskriminan.

\section{HASIL}

Dalam melakukan analisis skor IAT, diperoleh $D$-score yang dibentuk melalui penghitungan rerata reaction time jawaban benar dan standar deviasi (Greenwald, Nosek \& Banaji, 2003). Melalui program Inquisit, penghitungan $D$-score didapatkan secara 
otomatis ketika tes terselesaikan, sehingga dapat diketahui nilai besaran dan nilai sikap yang dimiliki oleh individu terhadap variabel tertentu. Penghitungan $D$-score secara manual dapat diperoleh melalui penghitungan mean latencies jawaban benar (reaction time) blok 2, blok 3, blok 4 dan blok 5 dan standar deviasi blok 2, blok 3, blok 4 dan blok 5. Expression.da didapatkan dari mean latencies jawaban benar blok 5 dikurangi mean latencies jawaban benar blok 3 dibagi dengan standar deviasi blok 3 dan blok 5. Expression. $d b$ didapatkan dari mean latencies jawaban benar blok 4 dikurangi mean latencies jawaban benar blok 2 dibagi dengan standar deviasi blok 4 dan blok 2. Kemudian nilai expression.da dan expression.db dijumlahkan dan dibagi dua. Dari penghitungan tersebut, diperoleh nilai D yang muncul di akhir pengujian. Bagan 2 merupakan visualisasi dari penjabaran tersebut.

Berdasarkan nilai $D$-score, peneliti melakukan pengujian korelasi antara $D$-score Alat Ukur Sikap terhadap Perilaku Wirausaha dengan Depression Brief IAT untuk pengujian validitas diskriminan pada kedua buah konstruk. Dari korelasi dua konstruk tersebut diperoleh hasil bahwa tidak terdapat korelasi yang signifikan ( $r .-0,266 ; p$. 0,97). Selain itu, peneliti juga menguji reliabilitas alat ukur dengan menggunakan 40 da dan $40 \mathrm{db}$ yang kemudian diuji menggunakan teknik analisis reliabilitas Guttman split-half. Berdasarkan hasil pengujian tersebut, diperoleh hasil koefisien reliabilitas sebesar 0,73. Wells dan Wollack (Azwar, 2012) menyebutkan bahwa koefisien reliabilitas yang dibutuhkan untuk memperoleh hasil yang reliabel adalah 0,70 .

Tabel 2

Hasil Pengambilan Data $(\mathrm{n}=40)$

\begin{tabular}{lcccc}
\hline $\begin{array}{l}\text { Stimulus } \\
\text { Target }\end{array}$ & $\begin{array}{c}\% \\
\text { Benar }\end{array}$ & $\begin{array}{c}\text { Minimal } \\
\text { (milisekon) }\end{array}$ & $\begin{array}{c}\text { Maksimal } \\
\text { (milisekon) }\end{array}$ & $\begin{array}{c}\text { Rata-Rata } \\
\text { (milisekon) }\end{array}$ \\
\hline Stimulus A & $98,01 \%$ & 375 & 2123 & 663 \\
Stimulus B & $94,63 \%$ & 383 & 1817 & 641,58 \\
Stimulus C & $96,67 \%$ & 342 & 2675 & 644,67 \\
Stimulus D & $95,95 \%$ & 370 & 1969 & 641,61 \\
Stimulus E & $98,68 \%$ & 363 & 1824 & 627,37 \\
Stimulus F & $95,97 \%$ & 325 & 1727 & 615,44 \\
Stimulus G & $98,68 \%$ & 367 & 2690 & 666,75 \\
Stimulus H & $95,66 \%$ & 352 & 1478 & 615,33 \\
\hline
\end{tabular}

Dari data yang diperoleh peneliti, sebanyak 40 data partisipan dianalisis mengenai stimulus target dan stimulus atribut yang digunakan dalam penelitian, sudah merupakan stimulus yang valid dan dapat digunakan dalam penelitian. Ketika respon berada kurang dari 300 milisekon dan melebihi 10.000 milisekon, maka respon tersebut dinyatakan tidak valid. 
Berdasarkan tabel 2, diketahui bahwa seluruh stimulus target merupakan gambar stimulus yang valid dan benar merepresentasikan perilaku wirausaha. Hal ini dikarenakan tidak ada nilai persentase benar di bawah $80 \%$ dan tidak ada nilai mean latency di bawah 300 milisekon dan di atas 10.000 milisekon.

Tabel 3

Hasil Pengambilan Data Atribut Baik (n=40)

\begin{tabular}{lcccc}
\hline $\begin{array}{l}\text { Stimulus } \\
\text { Target }\end{array}$ & $\begin{array}{c}\% \\
\text { Benar }\end{array}$ & $\begin{array}{c}\text { Minimal } \\
\text { (milisekon) }\end{array}$ & $\begin{array}{c}\text { Maksimal } \\
\text { (milisekon) }\end{array}$ & $\begin{array}{c}\text { Rata-Rata } \\
\text { (milisekon) }\end{array}$ \\
\hline Berani & $90,81 \%$ & 397 & 3324 & 776,95 \\
Inovatif & $91,35 \%$ & 317 & 3681 & 834,54 \\
Kerja Keras & $90,32 \%$ & 335 & 3421 & 838,02 \\
Kreatif & $88,83 \%$ & 368 & 2640 & 823,96 \\
Luwes Bergaul & $89,67 \%$ & 463 & 3308 & 793,83 \\
Mandiri & $90,43 \%$ & 328 & 2387 & 771,03 \\
Produktif & $87,37 \%$ & 324 & 2445 & 817,08 \\
Yakin Diri & $94,09 \%$ & 324 & 2831 & 774,53 \\
\hline
\end{tabular}

Berdasarkan tabel 3, diketahui bahwa seluruh stimulus atribut baik merupakan stimulus yang valid dan dapat digunakan dalam penelitian. Hal ini dikarenakan tidak ada nilai persentase benar di bawah $80 \%$ dan tidak ada nilai mean latency yang kurang dari 300 milisekon dan melebihi 10.000 milisekon.

Tabel 4

Hasil Pengambilan Data Atribut Buruk $(n=40)$

\begin{tabular}{lcccc}
\hline $\begin{array}{l}\text { Stimulus } \\
\text { Target }\end{array}$ & $\begin{array}{c}\% \\
\text { Benar }\end{array}$ & $\begin{array}{c}\text { Minimal } \\
\text { (milisekon) }\end{array}$ & $\begin{array}{c}\text { Maksimal } \\
\text { (milisekon) }\end{array}$ & $\begin{array}{c}\text { Rata-Rata } \\
\text { (milisekon) }\end{array}$ \\
\hline Asal Untung & $81,87 \%$ & 453 & 3562 & 870,51 \\
Gagal & $95,24 \%$ & 424 & 3843 & 719,84 \\
Kerugian & $90,22 \%$ & 425 & 3443 & 777,05 \\
Malas & $91,15 \%$ & 396 & 3481 & 795,84 \\
Manipulatif & $89,42 \%$ & 389 & 4481 & 832,51 \\
Menipu & $93,01 \%$ & 375 & 5508 & 810,76 \\
Rakus & $94,30 \%$ & 388 & 3241 & 768,28 \\
Tidak Jujur & $94,02 \%$ & 396 & 2507 & 724,60 \\
\hline
\end{tabular}

Berdasarkan tabel 4, diketahui bahwa seluruh stimulus atribut buruk merupakan stimulus yang valid dan dapat digunakan dalam penelitian. Hal ini dikarenakan tidak ada nilai persentase benar di bawah $80 \%$ dan tidak ada nilai mean latency yang kurang dari 300 milisekon dan melebihi 10.000 milisekon. 


\section{PEMBAHASAN}

Berdasarkan hasil yang diperoleh dari pengujian statistika, diperoleh hasil bahwa terdapat korelasi negatif yang tidak signifikan antara konstruk perilaku berwirausaha dengan konstruk depresi. Nisfiannoor (2009) menyebutkan bahwa nilai koefisien korelasi berentang 0,2 sampai 0,4 menunjukan bahwa konstruk yang dikorelasikan memiliki korelasi yang rendah. Dalam penelitian ini, korelasi antar perilaku berwirausaha dan depresi memiliki korelasi yang rendah ( $r=-0,266 ; p=0,97)$. Campbell (dalam Henseler, Ringle \& Sarstedt, 2015) menyebutkan bahwa korelasi yang rendah menunjukan bahwa kedua konstruk merupakan konstruk yang berbeda. Nilai korelasi negatif yang diperoleh dalam penelitian ini juga menunjukan perbedaan konstruk antar keduanya (Agho, Price, Mueller, 1992). Selain dari pada itu, korelasi yang tidak signifikan juga menunjukan bahwa dua konstruk yang sedang diukur merupakan konstruk yang berbeda (Brackett \& Mayer, 2003). Artinya bahwa konstruk perilaku berwirausaha merupakan konstruk yang unik dan tidak bisa diukur menggunakan alat ukur lain, khususnya alat ukur depresi (Hair, Black, Babin, \& Anderson, dalam Henseler, Ringle \& Sarstedt, 2015). Hal ini menunjukan bahwa Alat Ukur Sikap terhadap Perilaku Berwirausaha merupakan alat ukur yang valid berdasarkan validitas diskriminan. Peneliti juga memperoleh hasil bahwa seluruh stimulus target dan atribut dapat didiskriminasi ke dalam kategori yang benar oleh para partisipan dalam penelitian.

Hasil dari pengujian korelasi yang dilakukan dalam penelitian ini memberikan nilai korelasi yang negatif. Nilai korelasi yang negatif dalam pengujian korelasi antar perilaku wirausaha dan depresi menunjukan bahwa individu yang berperilaku wirausaha akan memiliki tingkatan depresi yang rendah. Hal ini sesuai dengan Bradley dan Roberts (2004) yang mengemukakan bahwa individu yang memiliki perilaku wirausaha tidak mengalami depresi. Pengujian yang dilakukan Bradley dan Roberts (2004) juga memberikan hasil pengujian asosiasi yang negatif antara wirausaha dengan depresi.

Pengujian validitas menggunakan validitas diskriminan memiliki kelemahan, yaitu hanya membandingkan dengan konstruk lain yang sama sekali berbeda. Berdasarkan kekurangan tersebut, disarankan peneliti yang tertarik untuk melanjutkan penelitian ini menguji validitas dengan validitas konvergen. Hal ini untuk mendapatkan kesamaan konstruk yang sedang diukur dalam pembentukan alat ukur. Kelemahan lainnya adalah minimnya partisipan dalam penelitian ini.

\section{DAFTAR PUSTAKA}

Agho, A. O., Price, J. L., \& Mueller, C. W. (1992). Discriminant validity of measures of job satisfaction, positive affectivity and negative affectivity. Journal of Occupational and Organizational Psychology, 65(3), 185-195. 
Anastasi, A., \& Urbina, S. (2007). Tes Psikologi (Psychological Testing). Jakarta: Indeks. Azwar, S. (2012b). Reliabilitas dan validitas. Yogyakarta: Pustaka Pelajar.

Badan Pusat Statistik. (2013). Proyeksi Penduduk Menurut Provinsi, 2010-2035 (ribuan). Retrieved 11 November 2017 from https://www.bps.go.id/linkTabelStatis/view/id/ 1274.

Baiquni, A. (2014). Jumlah tenaga kerja tak sebanding dengan lapangan pekerjaan. Retrieved 11 November 2017 from https://www.merdeka.com/uang/jumlah-tenagakerja-tak- sebanding-dengan-lapangan-pekerjaan.html.

Brackett, M. A., \& Mayer, J. D. (2003). Convergent, discriminant, and incremental validity of competing measures of emotional intelligence. Personality and Social Psychology Bulletin, 29(9), 1147-1158.

Bradley, D. E., \& Roberts, J. A. Self-Employment and Job Satisfaction: Investigating the Role of Self-Efficacy, Depression, and Seniority. Journal of Small Business Management 2004 42(1), pp. 37-58.

Central Intellegence Agency. (2017). The world factbook. Retrieved 11 November 2017 from https://www.cia.gov/library/publications/the-world-factbook/rankorder/2119 rank.html

Greenwald, Nosek dan Banaji. (2003). Understanding and using the implicit association test: I. An improved scoring algorithm. Journal of Personality and Social Psychology, 85(2), 197-216.

Greenwald, A.G., McGhee, D.E., \& Schwartz, J.L.K. (1998). Measuring individual differences in implicit cognition: The implicit association test. Journal of Personality and Social Psychology, 74, 1464-1480.

Hadian, D., Machmud, S., Juhana, D., \& Sidharta, I. (2015) Measuring theory planned behavior of Students to become Entrepreneurs (Case Study at School of Economic Pasundan Bandung, Indonesia). International Journal of Human Resource Studies, 5 (3), 131-147.

Hafiyah, N., Puri, A. dan Shadewi R. (2011). Menguji sikap implisit dengan Implicit Association Test. Sosial Humaniora, 15(2), 94-108.

Hartono, A. \& Suwartono, C. (2012). Pengukuran Self-Esteem dengan Metode Selfreport dan Implicit Association Test. Jurnal Pengukuran Psikologi dan Pendidikan Indonesia (JP3I), 2(2).

Hair Jr., J.F., Black, W.C., Babin, B., Anderson, R, 2014, Multivariate Data Analysis, Edinburgh: Pearson 
Henseler, J., Ringle, C. M., \& Sarstedt, M. (2015). A new criterion for assessing discriminant validity in variance-based structural equation modeling. Journal of the Academy of Marketing Science, 43(1), 115-135.

Kementrian Koperasi dan Usaha Kecil dan Menengah. (2017). Menteri Puspayoga target ratio kewirausahaan 2017 capai 4\%. Retrieved 11 November 2017 from http://www. depkop.go.id/content/read/menteri-puspayoga-target-ratio-kewirausahaan-2017capai-4/

Kolvereid, L. (1996). Prediction of employment status choice intentions. Entrepreneurship: Theory and Practice, 21(1), 47-58.

Lai, P. S. M. (2013). Validating instruments of measure: Is it really necessary? Malaysian family physician: the official journal of the Academy of Family Physicians of Malaysia, 8(1), 2.

Meites, T. M., Deveney, C. M., Steele K. T., Holmes A. J., \& Pizzagalli, D. A. (2008). Implicit depression and hopelessness in remitted depressed individuals. Behaviour Research and Therapy, 46, 1078-1084.

Myers, D., \& Twenge, J. (2013). Social psychology. New York: McGraw-Hill.

Perkins, A., Forehand, M., Greenwald, A., \& Maison, D. (2008). Measuring the nonconscious: Implicit social cognition on consumer behavior. In Haugvedt, C. P., Herr, P. M., \& Kardes, F. R (Eds.), Handbook of Consumer Psychology. Retrieved form https://faculty.washington.edu/agg/pdf/Perkins\%20et\%20al\%20Handbook\%20 Chapter.PDF

National Chamber Foundation. (2007). The millennial generation. Young, (February), 38. https://doi.org/10.1111/j.1553-2712.2011.01215.x

Nisfiannoor, M. (2009). Pendekatan statistika modern untuk ilmu sosial. Jakarta: Salemba Humanika.

Putra, R., I. (2013). Ini cara pemerintah kurangi pengangguran di Indonesia. Retrieved 11 November 2017 from https://www.merdeka.com/uang/ini-cara-pemerintahkurangi- pengangguran-di-indonesia.html

Rachman, F.F. (2017). Total 1,29 juta orang melamar cpns gelombang II. Retrieved October, 16, 2017 from https://finance.detik.com/berita-ekonomi-bisnis/3658249/ total-129-juta- orang-melamar-cpns-gelombang-ii

Stuttgen, P., Vosgerau, J., Messner, C., \& Boatwright, P. (2011) Adding significance to the implicit association test. Carnigie Mellon University.

Suharyadi. (2007). Kewirausahaan: Membangun usaha sukses sejak usia muda. Jakarta: Salemba Empat. 
Suwartono, C., Meinarno, E.A., \& Bawono, G. (2017). Development of the national identity measurement using the implicit association test method. Manuscript submitted for publication.

Tranding Economics. (N.A). Tingkat pengangguran-daftar negara. Retrieved 11 November 2017 from https://id.tradingeconomics.com/country-list/unemploymentrate.

Wardani, R., \& Analya, P. (2012). Sikap implicit mahasiswa terhadap peduli atau tidak peduli lingkungan. Universitas Maranatha.

Wittenbrink, B. \& Schwarz, N. (2007). Implicit measures of attitudes. New York: Guilford Press. 